\author{
Romana LAPA \\ Uniwersytet im. Adama Mickiewicza w Poznaniu \\ romalapa@amu.edu.pl \\ http://orcid.org/0000-0001-6862-5048
}

\title{
Z OPISU NOMINALIZACJI W TEKSTACH PRAWNYCH
}

\section{WPROWADZENIE}

Poniższe uwagi dotyczące prawnej odmiany języka koncentrują się wokół opisu współczesnych aktów normatywnych w postaci ustaw ${ }^{1}$. Jednym ze stylistycznych wyróżników wymienionych tekstów jest nominalność, która uwidacznia się w wysokim stopniu nasycenia struktur zdaniowych rzeczownikami i ograniczonym stosowaniu zdań złożonych na rzecz rozbudowanych wypowiedzeń pojedynczych. Nominalny charakter ustaw wypływa również z operowania konstrukcjami z przyimkiem, które obecne zarówno w grupie nominalnej, jak i werbalnej funkcjonują jako ekwiwalenty struktur opartych na verbum finitum (Łapa 2015: 294-296; zob. też: Jadacka 2006; Pawelec 2007)².

O tym, że tendencja do nominalizacji może uchodzić za swoiste kryterium wydzielania odmian współczesnej polszczyzny czytamy w opracowaniach językoznawczych wydanych w 2. połowie XX wieku. Autorzy

\footnotetext{
1 Ustawa to „akt uchwalany przez parlament (a nie jakiś inny organ państwowy) w specjalnej procedurze (w tzw. trybie ustawodawczym), którego elementy określa konstytucja, zajmujący pozycję bezpośrednio po konstytucji, mający nieograniczony przedmiotowo zakres normowania, co znaczy, że wszystkie dziedziny spraw mogą być regulowane ustawą, wszakże pod warunkiem zgodności tego uregulowania z konstytucją" (Wronkowska 2005: 32).

2 Ekspansja konstrukcji z przyimkami obok licznych konstrukcji werbo-nominalnych jest także uznawana za przejaw tendencji analitycznej, związanej z semantyzacją wyrażeń funkcyjnych.
} 
podnoszą ten aspekt, pisząc o języku gatunków prasowych i publicystyki naukowej (Jędrzejko 1993; Anusiewicz 1978; zob. też: Wilkoń 2000). Ewa Jędrzejko przypisuje zabiegom nominalizacyjnym w stylu odmian oficjalnych uniwersalny wymiar, mówi o ich występowaniu w innych językach. Twierdzi: „Gdy idzie o współczesną polszczyznę, to dostrzega się w tym procesie także przejaw pogłębiania się cech przynależności do europejskiej ligi «frazeologicznej»" (1993: 80).

Z punktu widzenia składniowego nominalizacja obok sentencjalizacji stanowi jedną $\mathrm{z}$ technik formalizacyjnych bazowego zdania semantycznego. Zuzanna Topolińska, badając strukturę grupy imiennej, pisze: „Przez nominalizację rozumie się żywy, należący do gramatyki danego języka proces imiennej formalizacji danej (scharakteryzowanej) struktury predykatowo-argumentowej, traktowanej jako hipotetyczny model zdania w płaszczyźnie semantycznej. Rezultatem tego procesu jest taki typ grupy imiennej, która na płaszczyźnie składniowej (formalnej) jest w określony sposób skorelowana ze zdaniem, czyli werbalną realizacją tego samego modelu propozycjonalnego" (1984: 355). Produkty nominalizacji powstają w drodze różnych zabiegów, nie tylko przez substantywizację czasownika w drodze transpozycji słowotwórczej lub leksykalnej (supletywnie), lecz także przez adiektywizację, która przekształca czasownik w przymiotnik lub imiesłów odmienny, albo przez zmianę funkcji przymiotnika z predykatywnej na atrybutywną, co pociąga za sobą zmianę szyku i elipsę kopuli: uchwyt jest metalowy - metalowy uchwyt (Jędrzejko 1993: 28).

W dalszej części poza jednym wyjątkiem przedmiotem opisu czynię konstrukcje składniowe powstałe $\mathrm{w}$ drodze derywacji morfologicznej ${ }^{3}$, konstytuowane przez rzeczownik zdarzeniowy (skrót GN). W zdaniu normatywnym zajmują one inicjalną pozycję podmiotu. Przekazują treść, która stanowi kontekst sytuacyjny dla zdarzenia ujętego osobową formą czasownika bądź konstrukcją werbalną. Specyfika GN polega na tym, że są wskaźnikami międzyzdaniowego nawiązania ${ }^{4}$. Innymi słowy, funk-

\footnotetext{
3 Omawiane konstrukcje to inaczej produkty nominalizacji właściwej, substantywnej (Jędrzejko 1993: 34).

4 Zenon Klemensiewicz odróżnia syntaktyczny stosunek nawiązania od syntaktycznego stosunku zespolenia: „Analiza syntaktyczna ogranicza się właściwie do zdania pojedynczego oraz zdania dwuczłonowego lub wielokrotnie złożonego. A przecież jest rzeczą oczywistą, że także w rozleglejszej wypowiedzi, na którą składa się mniejszy lub większy zespół zdań, istnieją jakieś stosunki syntaktyczne. Ich wykrycie i określenie ma wielką wartość dla strukturalnego ujęcia tworów językowych i powinno kiedyś oddać pewne usługi pożądanej ich analizie stylistyczno-gramatycznej. Niniejszy artykuł [O syntaktycz-
} 
cjonują jako wykładniki relacji anaforycznej czy też izotopicznej, której charakterystykę przynoszą omówienia poświęcone zarówno strukturom składniowym, jak i tekstom rozumianym jako językowe całości ponadzdaniowe (m.in.: Topolińska 1984: 326-327; Krążyńska, Mika, Słoboda 2016: 142; Dobrzyńska 1993b: 28-30, 1993a: 294; Żydek-Bednarczuk 2005: 98-106).

Wyszczególnione GN, podobnie jak zaimki i inne wyrażenia w funkcji nawiązującej ${ }^{5}$, służą spójności tekstu, zachowaniu w nim głównej linii tematycznej, postrzeganiu go jako uporządkowanej i zwartej całości. $\mathrm{W}$ dokumentach prawnych spójność i sprzężona $\mathrm{z}$ nią zwięzłość dochodzą do głosu za sprawą odesłań; zarówno wewnętrznych, jak i zewnętrznych ${ }^{6}$. Istnienie wewnątrz- i międzytekstowych odniesień jest określone przez dwie techniki konstruowania tekstu prawnego: kondensację i rozczłonkowanie norm. Kondensacja wiąże się z tym, że w jednym przepisie mogą być wyrażone elementy wielu norm postępowania (Zieliński 1992: 109; Wronkowska 2005: 64). Rozczłonkowanie norm może być syntaktyczne lub treściowe. Jeśli ma wymiar syntaktyczny, to oznacza, że prawoznawca umieszcza wyrażenia składowe określonej normy w różnych przepisach (Zieliński 1992: 110; Wronkowska 2005: 64). Jeżeli rozczłonkowanie jest treściowe, w tekście prawnym występują przepisy, które modyfikują treść normy wysłowionej w przepisie zrębowym (Zieliński 1992: 112)7.

nym stosunku nawiązania - R. Ł.] jest taką próbą charakterystyki stosunków syntaktycznych miedzy zdaniami większej wypowiedzi; ten ich typ nazywam właśnie syntaktycznym stosunkiem nawiązania w odróżnieniu od syntaktycznego stosunku zespolenia w obrębie jednego zdania złożonego" (1982: 241).

5 Teoretycy prawa do środków w funkcji nawiązującej włączają m.in. zwroty w przepisach odsyłających, nakazujące albo uwzględnienie treści przepisów, do których następuje odesłanie, albo uwzględnienie treści przepisu przywołanego, który uzupełnia treść przepisu odsyłającego: w przypadku ... stosuje się odpowiednio przepisy o ..., w sprawach nieuregulowanych ... stosuje się przepisy ..., przepisy o ... maja zastosowanie do ... W wypadku intertekstualności ważne jest zamieszczanie w jednym tekście fragmentu innego aktu prawnego albo przywoływanie podstawy prawnej ustanowienia danego aktu (Chodun 2006: 92, 95-105).

6 Odesłania wewnętrzne są charakterystyczne dla przepisu prawnego, który odnosi się do innego przepisu bądź przepisów tego samego aktu. Odesłania zewnętrzne mogą dotyczyć przepisu lub przepisów innego aktu normatywnego albo przepisów innego aktu normatywnego (zewnętrzne) i innych swoich przepisów. Oprócz odesłań wewnątrzsystemowych, działających w ramach systemu prawa, wyróżnia się odesłania pozasystemowe, które nawiązują do norm i zasad postępowania spoza systemu prawnego (Wronkowska 2005: 71). Ważność odesłań do innych przepisów prawnych jako czynnika, który zapewnia aktom normatywnym spójność semantyczną, podkreśla Choduń (2006: 90).

7 Zieliński sygnalizuje, że rozczłonkowanie treściowe jest ważniejsze aniżeli rozczłon- 
Rozpoznanie zależności anaforycznej wymaga umieszczenia w centrum uwagi nie tylko GN, lecz także antepozycyjnych względem nich wypowiedzeń. W ustawach mamy do czynienia ze swoistym, niejednolitym usytuowaniem konstrukcji objętych anaforą. Piszę na ten temat w innym artykule (2016), tutaj jedynie przypomnę, że GN mogą odsyłać do treści wyrażonej w linearnie wcześniejszym zdaniu, które bezpośrednio sąsiaduje z GN (tak jest w nierozbudowanym artykule), stanowi kolejny paragraf albo jest odrębnym artykułem.

W badaniach nad konstrukcjami po nominalizacji znaczące miejsce zajmuje koncepcja składni oparta na podstawach semantycznych. Przyjmuje się $\mathrm{w}$ niej istnienie wyjściowego semantyczno-logicznego modelu zdania, który należy do poziomu głębokiego. Odpowiednio zinterpretowana głęboka struktura treściowa wyróżnia się tym, że można jej przyporządkować dwie powierzchniowe realizacje: zdanie i grupę, powiązane siecią zależności, podobieństw i odrębności. Analiza GN powstałych w drodze nominalizacji właściwej - substantywnej uświadamia ważność kwestii tj.: możliwości odtworzenia w GN aktantów ujawnionych $\mathrm{w}$ wariancie zdaniowym, ograniczenia $\mathrm{w}$ powierzchniowej realizacji aktantów, przejmowanie przez rzeczownik dewerbalny schematu walencyjnego właściwego dla jego podstawy, kształtowanie się nowego układu cech walencyjnych dla rzeczownika zdarzeniowego (zob.: Jędrzejko 1993: 60 i in.).

Opisowi GN pochodzących z dokumentów prawnych przyświecają następujące cele: wskazanie podstaw derywacyjnych GN, omówienie ich strukturalnego kształtu i przedstawienie następstw, jakie w formalizacji elementów bazy semantycznej pociąga za sobą nominalizacja bazująca na derywowanym rzeczowniku.

\section{TYPY PODSTAW DERYWACYJNYCH GN}

Podstawę konstytutywnego nomen stanowią różne wyrażenia obecne w antepozycyjnym zdaniu, głównie czasowniki. Dominują współtworzące konstrukcję werbalną bezokoliczniki:

kowanie syntaktyczne. Pisze ponadto: „,[...] należy pamiętać, że prawodawca wypowiada się w całym tekście prawnym, i że treść danej normy musi być adekwatna do całego tekstu prawnego $w$ tym sensie, że nie może pominąć żadnego przepisu, który ją rzeczywiście wyznacza" (1992: 112). 
Kapitan może w czasie podróży zatrzymać w osobnym pomieszczeniu osobę, której zachowanie się na statku zagraża bezpieczeństwu statku, ludzi lub mienia. Zatrzymanie może trwać najdłużej do czasu przybycia statku do najbliższego portu polskiego albo do portu państwa, którego obywatelem jest osoba zatrzymana. (art. 68 § 1 k.m.)

Wymienioną funkcję pełnią konstytuujące wypowiedzenie formy osobowe czasownika:

Zarzą ogłasza dwukrotnie wezwanie o dokonanie wpłat. (art. 330 $\S 2$ k.s.h.)

Pierwsze ogłoszenie powinno być dokonane na miesiąc, a drugie nie później niż na dwa tygodnie przed terminem wptaty. (art. $330 § 3$ k.s.h.)

W odrębną, charakterystyczną klasę układają się wykładniki normatywnej kwalifikacji zdarzenia - operatory modalne:

Jeżeli istnieje niebezpieczeństwo pogorszenia rzeczy, kupujący jest uprawniony, a gdy interes sprzedawcy tego wymaga - obowiazany sprzedać rzecz $z$ zachowaniem należytej staranności. Powyższe uprawnienie przystuguje kupujacemu także wtedy, gdy sprzedawca zwleka z wydaniem dyspozycji. (art. $567 \S 2$ k.c.)

Inne anaforyzowane wyrażenia to rzeczowniki bezpośrednio przyłączane przez verbum finitum lub konstrukcję werbalną. Anaforyzująca GN jest dokładnym powtórzeniem:

Za wydanie dokumentu rejestracyjnego urząd morski pobiera opłatę. Optata stanowi dochód budżetu państwa. (art. 39 § 3 k.m.)

Przewoźnik ma prawo domagać się od czarterującego odszkodowania za rzeczywiście poniesiona szkodę spowodowana odstapieniem przez czarterujacego od umowy przewozu zawartej na szereg kolejnych podróży lub na przewóz określonej ilości ładunku. Odszkodowanie to nie może jednak przekraczać wysokości frachtu, jaki przypadałby za anulowane podróże. (art. 160 § 3 k.m.)

Do anaforyzowanych rzeczowników należą składniki konstrukcji z przyimkami:

Organ, o którym mowa w art. 74, może nakazać właścicielowi lub zarzadcy, w drodze decyzji, zabezpieczenie miejsca katastrofy oraz obiektu budowlanego, który uległ katastrofie, uporzadkowanie terenu lub wyko- 
nanie innych niezbędnych czynności i robót budowlanych. Decyzja podlega natychmiastowemu wykonaniu i może być ogłoszona ustnie. (art. 76 p. 4 pr.bud.)

Potracenia dokonywa się przez oświadczenie złożone drugiej stronie. Oświadczenie ma moc wsteczna od chwili, kiedy potracenie stało się możliwe. (art. 499 k.c.)

\section{NASTĘPSTWA PROCESÓW NOMINALIZACYJNYCH}

Zważywszy na to, że zdanie i grupa stanowią dwie formalnie różne konstrukcje składniowe służące przekazywaniu tej samej treści propozycjonalnej, trzeba mieć świadomość, że pozwalają one na ujęcie zdarzenia z innej perspektywy. Treść niesiona przez wypowiedzenie ma wymiar sytuacyjny, co oznacza, że jest w nim możliwa w miarę pełna charakterystyka zdarzenia:

Korzystający powinien niezwłocznie zawiadomić finansujacego o utracie rze$c z y$. (art. $709 \S 2$ k.c.)

Zdanie dostarcza konkretnych informacji o działaniu (zawiadamiać). Jest w nim mowa o uczestniczących w nim osobowych aktantach, tj.: agensie (korzystajacy) i pacjencie (finansujacy). Zakres działania precyzuje konstrukcja z przyimkiem (o utracie rzeczy). Współtworzący konstrukcję werbalną operator modalny powinien jest wykładnikiem normatywnej kwalifikacji zdarzenia, tzn. wyraża obowiązek spoczywający na aktancie w pozycji podmiotu i implikuje prawo przysługujące drugiemu osobowemu uczestnikowi zdarzenia. Struktura zdaniowa daje sposobność charakterystyki zdarzenia od strony temporalnej, przy czym $\mathrm{w}$ wypadku analizowanego przykładu istotą działania jest potencjalność, zakładająca jego realizację $\mathrm{w}$ przyszłości. Potencjalność oddaje operator modalny, w myśl założeń wypracowanych na gruncie logiki kwalifikujący zdarzenia jako należące do tzw. możliwych światów (Grzegorczykowa 2001: 124; Łapa 2015: 109).

W badanych ustawach do nielicznych należą rozbudowane GN, w których dochodzi do ujawnienia aktantów obecnych w wariancie zdaniowym. Różnica między zdaniem a GN sprowadza się do nieodtworzenia we frazie kwalifikacji modalnej: 
Spótka może finansować nabycie lub objęcie emitowanych przez niq akcji, o ile uprzednio otworzyła na ten cel kapitat rezerwowy z kwoty, która zgodnie z art. $348 \S 1$ może być przeznaczona do podziału. (art. 345 $\S 4$ k.s.h.)

Finansowanie przez spółkę nabycia lub objęcia emitowanych przez nia akcji nastęuje na podstawie $i$ w granicach $w$ uprzednio podjętej uchwale walnego zgromadzenia. (art. $345 \S 5$ k.s.h.)

Zwykle we wskazanym typie GN dane o zdarzeniu są bardziej uszczuplone:

Komplementariusz może wnieść wkład do spótki komandytowo-akcyjnej na kapitat zakładowy lub na inne fundusze. (art. $132 \S 1$ k.s.h.)

Wniesienie przez komplementariusza wkładu na kapitat zakładowy nie wyłącza jego nieograniczonej odpowiedzialności za zobowiązania spótki. (art. $132 \S 2$ k.s.h.)

W skład frazy konstytuowanej przez rzeczownikową nazwę czynności wchodzą wykładniki partycypantów tj.: 'sprawca', 'obiekt' i 'przeznaczenie'.

W rozbudowaną klasę układają się GN mniejszych rozmiarów, zazwyczaj dwu- lub trójskładnikowe. Obrazują one, zbadaną zarówno w tekstach polszczyzny współczesnej, jak i w materiale historycznym, tendencję do kondensacji treści, która sprawia, że na powierzchni realizują się aktanty silnie rządzone i ważne komunikacyjnie. Wyekscerpowane GN wyróżniają się z punktu widzenia strukturalnego, gdyż w ich obrębie powstają skupienia derywatów odczasownikowych, tzw. nominalizacje piętrowe (Jędrzejko 1993: 88; Łapa 2015: 295). Konstytuujący GN rzeczownik dewerbalny na niższym poziomie składniowym otwiera miejsce, najczęściej w dopełniaczu, dla innego rzeczownika transpozycyjnego:

Spadkobierca ustawowy może przez umowę najmu z przyszłym spadkodawca zrzec się dziedziczenia po nim. Umowa taka powinna być zawarta w formie aktu notarialnego. (art. 1048 k.c.)

Zrzeczenie się dziedziczenia obejmuje również zstępnych zrzekającego się, chyba że umówiono się inaczej. (art. 1049 § 1 k.c.).

Przyłącza też dwa rzeczowniki stanowiące szereg:

Spadkobiercy obowiazani do zaspokojenia roszczenia z tytułu zachowku moga żądać stosunkowego zmniejszenia zapisów i poleceń. (art. 1003 k.c.) 
Zmniejszenie zapisów i poleceń następuje w stosunku do ich wartości, chyba że z treści testamentu wynika odmienna wola spadkodawcy. (art. 1004 $\S 1$ k.c.)

Składniki podrzędne w dopełniaczu są nie tylko wykładnikami znaczenia 'akcja'. W tórnie mogą wskazywać na 'obiekt'. W ich roli występują wówczas nazwy dokumentów administracyjno-prawnych:

Jeżeli podanie wniesiono do organu niewłaściwego, a organu właściwego nie można ustalić na podstawie danych podania, albo gdy z podania wynika, że właściwym w sprawie jest sąd powszechny, organ, do którego podanie wniesiono, zwraca je wnoszacemu. Zwrot podania następuje w drodze postanowienia, na które stuży zażalenie. (art. 66 § 3 k.p.a.)

Sprostowania dokonuje organ, który popełnił omyłkę. Jeżeli postępowanie toczy się przed instancja odwoławcza, może ona z urzędu sprostować orzeczenie pierwszej instancji. (art. 105 § 2 k.p.k.)

Sprostowanie orzeczenia lub jego uzasadnienia następuje w drodze postanowienia, a sprostowanie zarzadzenia w drodze zarzadzenia. (art. 105 $\S 3$ k.p.k.)

Podrzędny rzeczownik sygnalizuje również 'środek płatniczy':

Spółka może upoważnić zarząd do wypłaty zaliczki na poczet przewidywanej dywidendy na koniec roku obrotowego, jeżeli spótka posiada środki wystarczajace na wypłate. Wyptata zaliczki wymaga zgody rady nadzorczej. (art. $349 \S 1$ k.s.h.)

Z tą samą sytuacją mamy do czynienia, jeśli określnik konstytutywnego nomen ma postać wyrażenia przyimkowego:

Stronie, która poniosła szkodę na skutek uchylenia lub zmiany decyzji, służy roszczenie o odszkodowanie za poniesiona rzeczywista szkodę od organu, który uchylit lub zmienił tę decyzję. (art. $161 \S 3$ k.p.a.)

Roszczenie o odszkodowanie przedawnia się z uptywem trzech lat od dnia, w którym stała się ostateczna decyzja uchylająca lub zmieniająca decyzję. (art. $161 \S 4$ k.p.a.)

W tym miejscu trzeba odnotować, że zanalizowana w tekstach prawnych depersonalizacja (Wojtak 1993: 153; Łapa 2015: 297) nie jest ich cechą bezwarunkową, obligatoryjną. W omawianych ustawach oprócz GN z nieujawnionym znaczeniem kategorialnym 'sprawca' można zaobserwować 
frazy ze sformalizowanym osobowym aktantem, które niekoniecznie są bardzo rozbudowane:

$W$ umowie agencyjnej zawartej w formie pisemnej można zastrzec, że agent za odrębnym wynagrodzeniem (prowizja del credere), w uzgodnionym zakresie, odpowiada za wykonanie zobowiazania przez klienta. (art. 761 \$ 1 k.c.)

Odpowiedzialność agenta może dotyczyć tylko oznaczonej umowy lub umów z oznaczonym klientem. (art. 761 § 2 k.c.)

Jeśli chodzi o najwyższy stopień kondensacji treściowej, to jest widoczny w jednoskładnikowych GN. Przynoszą one okrojoną, uogólnioną charakterystykę zdarzenia, bez wskazania na jego indywidualne cechy (Jędrzejko 1993: 88-89):

Osoby przestuchiwane moga być konfrontowane w celu wyjaśnienia sprzeczności. Konfrontacja nie jest dopuszczalna w wypadku określonym w art. 184. (art. 172 k.p.k.)

Osobie przesłuchiwanej można okazać inna osobę, jej wizerunek lub rzecz w celu jej rozpoznania. Okazanie powinno być przeprowadzone tak, aby wyłaczyć sugestię. (art. 173 § 1 k.p.k.)

GN nierozwinięte wyróżniają się spośród zebranych przykładów również dlatego, że najwymowniej obrazują podstawowy efekt formalizacji imiennej, mianowicie tendencję do autonomizacji. Innymi słowy, idzie o przejście od języka konkretnego, związanego z określoną sytuacją do języka abstrakcyjnego, abstrahującego od sytuacyjności (Skudrzyk 2005: 144). Spostrzeżenie powyższe koresponduje z tezami kognitywizmu mówiącymi o braku symetrycznej zależności między zjawiskami w rzeczywistości pozajęzykowej a sposobem ich konceptualizacji (Langacker 1983: 115).

Efektem ujęcia zdarzenia za pomocą rzeczownika jest postrzeganie go jako obiektu (Jędrzejko 1993: 34; Krążyńska, Mika, Słoboda 2015: 130). Na ten temat autorzy Składni średniowiecznej polszczyzny piszą: „Tak skategoryzowana czynność zostaje nie tylko oderwana od wykonawcy, ale także od czasu i przestrzeni. Staje się pojęciem. Można wówczas zwrócić uwagę na podobne do siebie czynności, na ich liczbę, różnorodność, można wskazać ich cechy. Można o tych elementach orzekać" (Krążyńska, Mika, Słoboda 2015: 130).

$\mathrm{W}$ tekstach prawnych $\mathrm{w}$ związku $\mathrm{z}$ uabstrakcyjnieniem treści zdarzeniowej podkreślenia wymagają dwie kwestie. Pierwsza dotyczy licz- 
nych GN, w których - było to już widać we wcześniej opisanych frazach - doszło do modyfikacji niesionego przez nie znaczenia czynnościowego. Ewa Jędrzejko zauważa, że zależności formalizacyjne niejednokrotnie układają się w pasmo „rosnącej nominalizacji”. Tworzą je czasownik, transpozycyjna nazwa zdarzenia i wykładniki wtórnych znaczeń przedmiotowych (mutacyjne derywaty obiektowe), np.: mieszkać - mieszkanie 'czynność' - mieszkanie 'obiekt'; ubrać - ubranie 'czynność' - ubranie/ubiór 'strój' (1993: 35). Powtórzę, że w ustawach rzeczownikowe wykładniki znaczeń przedmiotowych funkcjonują jako nazwy dokumentów administracyjno-prawnych:

Makler morski podejmuje się za wynagrodzeniem na podstawie każdorazowego zlecenia, pośredniczenia w zawieraniu umów sprzedaży statków, umów przewozu, czarteru na czas, umów holowniczych, umów ubezpieczenia morskiego i innych umów związanych z obrotem morskim. (art. 208 § 1 k.m.)

Zlecenie może objąć załatwianie dla statku wszelkich czynności związanych z jego przejściem, postojem $i$ wyjściem, a także innych czynności należących do zakresu działania agenta morskiego (art. $208 \S 2$ k.m.)

Zarzad ogłasza dwukrotnie wezwanie o dokonanie wpłat. (art. $330 \S 2$ k.s.h.)

Pierwsze ogłoszenie powinno być dokonane na miesią, a drugie nie później niż na dwa tygodnie przed terminem wptaty. (art. $330 § 3$ k.s.h.)

Potrącenia dokonywa się przez oświadczenie złożone drugiej stronie. Oświadczenie ma moc wstecznq od chwili, kiedy potrącenie stało się możliwe. (art. 499 k.c.)

Kolejna cecha stanowiąca następstwo uogólniania przekazywanej treści to terminologizacja (zob.: Krążyńska, Mika, Słoboda 2015: 156). Obejmuje ona nazwy czynności związanych z daną regulacją i określenia dokumentów prawnych, ale nie tylko. Polega również na urzeczowieniu prymarnie wyrażanej przez operator modalny kwalifikacji normatywnej. Efektem nominalizacji są terminy, m.in.: uprawnienie i prawo do czegoś, które współtworząc prawoznawczą aparaturę pojęciową, służą opisowi sytuacji prawnych (Wronkowska, Ziembiński 2001: 103-111):

Jeżeli istnieje niebezpieczeństwo pogorszenia rzeczy, kupujący jest uprawniony, a gdy interes sprzedawcy tego wymaga - obowiazany sprzedać rzecz $z$ zachowaniem należytej staranności. Powyższe uprawnienie przysługuje 
kupującemu także wtedy, gdy sprzedawca zwleka z wydaniem dyspozycji. (art. $567 \S 2$ k.c.)

Frachtujacy może po załadowaniu odstapić od umowy do chwili rozpoczęcia podróży i domagać się wyładowania ładunku, jest jednak obowiązany zapłacić cały fracht oraz koszty spowodowane odstapieniem od umowy. Prawo to nie służy frachtującemu, jeżeli wyładowanie jego ładunku spowodowałoby istotne opóźnienie rozpoczęcia podróży. (art. 159 § 2 k.m.)

\section{PODSUMOWANIE}

W odznaczających się nominalnością ustawach ważne miejsce zajmują GN powstałe $\mathrm{w}$ drodze derywacji morfologicznej. W zdaniu normatywnym są one różnie usytuowane, m.in. licznie pojawiają się w inicjalnej pozycji podmiotu. Pełniona przez nie funkcja anaforyczna jest związana z tematyzacją zdarzenia, które stanowi kontekst sytuacyjny dla czynności wyrażonej konstrukcją werbalną bądź verbum finitum.

Specyfika GN polega na tym, że w opozycji do wypowiedzenia dają sposobność sformalizowania wybranych, najistotniejszych konotacyjnie i treściowo aktantów. Stanowią zbiór - myślę o frazach dwu- i trójskładnikowych - dość jednorodny, układający się w powtarzalne schematy strukturalne. Tym, co je wyróżnia, są, co prawda, nie tak wyraziste jak w grupie werbalnej, bo obejmujące zazwyczaj tylko dwa poziomy składniowe, skupienia rzeczowników dewerbalnych. Opis jednoskładnikowych GN, oddających najwyższy stopień uabstrakcyjnienia zdarzenia, uświadamia konsekwencje zabiegów nominalizacyjnych: przesunięcia znaczeniowe $w$ obrębie rzeczowników transpozycyjnych i rozwój terminologii.

\section{WYKAZ AKTÓW NORMATYWNYCH}

k.c. - ustawa z dnia 23 kwietnia 1964 r. - Kodeks cywilny (Dz.U. Nr 16, poz. 93 z póź. zm.)

k.m. - ustawa z dnia 18 września 2001 r. - Kodeks morski (Dz.U. Nr 138, poz. $1545 \mathrm{z}$ póź. zm.)

k.p.a. - ustawa z dnia 14 czerwca 1960 r. - Kodeks postępowania administracyjnego (Dz.U. z 1980 r., Nr 9, poz. 26 z póź. zm.)

k.p.k. - ustawa z dnia 6 czerwca 1997 r. - Kodeks postępowania karnego (Dz.U. Nr 89, poz. 555 z póź. zm.) 
k.s.h - ustawa z dnia 15 września 2000 r. - Kodeks spółek handlowych (t.j. Dz.U. z 2013 r., poz. 1030)

p.p.s.a. - ustawa $z$ dnia 30 sierpnia 2002 r. - Prawo o postępowaniu przed sądami administracyjnymi (t.j. Dz.U. z 2012 r., poz. 270)

pr.bud. - ustawa z dnia 7 lipca 1994 r. - Prawo budowlane (Dz.U. z 2013 r., poz. 1409)

\section{BIBLIOGRAFIA}

Anusiewicz J., 1978, Konstrukcje analityczne we wspótczesnym języku polskim, Wrocław.

Chodun A., 2007, Słownictwo tekstów aktów prawnych w zasobie leksykalnym wspótczesnej polszczyzny, Warszawa.

Dobrzyńska T., 1993a, Tekst, [w:] Współczesny język polski, red. J. Bartmiński, Wrocław, s. 283-304.

Dobrzyńska T., 1993b, Tekst. Próba syntezy, Warszawa.

Grzegorczykowa R., 2001, Wprowadzenie do semantyki językoznawczej, Warszawa. Jadacka H., 2006, Poradnik językowy dla prawników, Warszawa.

Jędrzejko E., 1992, Nominalizacje w języku i w tekstach wspótczesnej polszczyzny, Katowice.

Klemensiewicz Z., 1982, O syntaktycznym stosunku nawiazania, [w:] Składnia, stylistyka, pedagogika jezzykowa, red. A. Kałkowska, Warszawa, s. 241-257.

Krążyńska Z., Mika T., Słoboda A., 2016, Składnia średniowiecznej polszczyzny, Poznań 2016.

Langacker R., 1983, Foundations of Cognitive Grammar, Bloomington.

Łapa R., 2015, Język prawny w świetle analizy językoznawczej. Wybrane zagadnienia składniowe, Poznań.

Łapa R., 2016, Grupa nominalna w ustawach. System wewnątrztekstowych odniesień, "Slavia Occidentalis. Linguistica", t. 73/1, s. 95-104.

Pawelec R., 2007, Zrozumiałość i poprawność składniowa tekstów prawnych a problem nominalizacji, [w:] Język polskiej legislacji, czyli zrozumiałość przekazu a stosowanie prawa. Materiaty z konferencji zorganizowanej przez Komisję Kultury i Środków Przekazu oraz Komisje Ustawodawcza Senatu RP, Warszawa, s. 65-70.

Skudrzyk A., 2005, Czy zmierzch kultury pisma? O synestezji i analfabetyzmie funkcjonalnym, Katowice.

Topolińska Z., 1984, Składnia grupy imiennej, [w:] Gramatyka wspótczesnego języka polskiego. Składnia, Warszawa, s. 301-389.

Wilkon A., 2000, Typologia odmian językowych wspótczesnej polszczyzny, Katowice.

Wronkowska S., 2002, Podstawowe pojęcia prawa i prawoznawstwa, Poznań.

Ziembiński Z., Zieliński M., 1992, Dyrektywy i sposób ich wypowiadania, Warszawa. Żydek-Bednarczuk U., 2005, Wprowadzenie do lingwistycznej analizy tekstu, Kraków. 


\title{
FROM A DESCRIBTION OF NOMINALIZATIONS \\ IN LEGAL TEXTS
}

\begin{abstract}
Summary
This paper deals with a nominal group (NG) of contemporary legal texts which have the form of statutes. The linguistic analysis based on the syntactic model with semantic rudiments. The author researches the anaphoric relation between nominal groups and sentences which are linearly prior to these groups. The nominal groups are products of the morpfological nominalization - substantivization. The analysis provides observation about restrictions in the formalization of elements of the semantic base whose elements can be connected with the use of nominal group. The author describes the different effects of nominalization, for example: condensation of content (from a very pure content of syntactic units to the cumulation of content in syntactic units), the tendency to autonomize the language (the disconnection of language and reality).
\end{abstract}

Key words: legal language, nominalization, nominal group, sentence 